\title{
PARENTS' EXPERIENCES REGARDING THE COMING-OUT PROCESS OF A GAY OR LESBIAN CHILD
}

\section{Assim Alpaslan, Theresa Johnston, Veonna Goliath \\ INTRODUCTION AND PROBLEM FORMULATION}

Coming out of the closet, that is, identifying or labelling oneself publicly as gay or lesbian, is one of the most difficult and potentially traumatic experiences a gay/lesbian person can undertake (Woog, 1997). For many gays/lesbians this process is a journey which starts at the first awareness of being different from others. It then follows the route of coming out to oneself - labelling oneself as gay/lesbian - and finally letting others know of one's sexual orientation. A large amount of the gay/lesbian person's energy goes into deciding where, when, how and to whom he/she will disclose his/her sexual orientation. They are greatly concerned about the possible risks and consequences of "coming out" to significant others (Moses, 1986:80).

One of the major obstacles in the process of coming out to one's heterosexual family members is the possible risk of being rejected, being subjected to abuse, parental distancing, even being "disowned" and losing one's ties to the biological kin (Goffman, 1997:30; Saltzburg, 2007:58). It introduces into the lesbian/gay person's awareness the fact of continuation versus termination of family-of-origin relationships, which is entirely voluntary on the part of parents and children. Therefore, the gay/lesbian child or sibling's possibility of being completely cut off or marginalised by their family is one that gay/lesbian persons must contemplate seriously (Green, 1996).

In light of the risk of being marginalised and/or cut off, gays and lesbians do not come out to their parents and siblings at once. According to LaSala (2000), it seems likely that gay/lesbian offspring make cost-and-benefit appraisals when deciding whether to come out to either their parents and/or their siblings. Chan (1989:24) and Green (1996) state that for a child to disclose his or her gay or lesbian sexual orientation to a parent(s) will be dependent on the following:

- the pre-existing levels of closeness, openness and conflict that exist in each parent-child dyad;

- the amount of contact (time spent together) between the parent and child;

- the salience of the parents as a social support, social identity and economic support;

- the availability of other resources of social support, social identity and economic support (for example, friends, family of choice, employment outside the family);

- the individual's appraisal of the costs and benefits to self, to the parent and to their relationships, based on the anticipated responses of the family members.

Gay/lesbian offspring also make some predictions about their parents' likely responses to the news, and they probably base this appraisal on specific knowledge of the parents' attitudes towards sexuality in general and homosexuality in particular. Hawkins (1996:1) states: “...that a gay or lesbian child may be overcome with guilt regarding their hidden sexual identity and as a result reveal their sexual preference." Green (1996) supports this by saying that gay/lesbian children who have more contact, emotional closeness, openness of communication and less conflict with their parents seem more likely to come out, whereas individuals whose family relationships are the opposite seem less likely to come out. In other words, the decision to come out to parents is clearly based on the realistic estimate of the parents' likely response and the 
nature and quality of the parent-child relationship, and may cause a family crisis. In relation to the latter, LaSala (2000) states: “A son/daughter's announcement of being gay/lesbian might precipitate the same family crisis as a son or daughter announcing to parents that he/she is involved in a relationship with someone from a different class, race and/or religion [or that he/she is going to marry such a person]."

A literature search (specifically of journal articles) conducted on the topic pointed to the fact that, although a number of articles focus on the topic of the coming-out process of gay and lesbian youths as it relates to their parents do exist (Amnesty International, 1998; Ben-Ari, 1995a, 1995b; Berzon, 2000; Falzarano, 1997; Fields, 2001; Gabriel 2001; Green, 1996; Saltzburg, 2007; Savin-Williams, 1989; Warren \& Wiedenkeller, 1993; Woog, 1997), the aspect of parents' experiences and reactions consequent to the coming out of a gay/lesbian offspring seems to be less frequently documented in the literature. From the literature consulted only the publications by Ben-Ari (1995a), Ben-Ari (1995b), Fields (2001), Green (1996), Saltzburg (2007) and Warren and Wiedenkeller (1993), articulated the experiences and reactions of parents in relation to the coming out of a gay/lesbian child. None of the aforementioned studies were done in South Africa; therefore the researchers deemed this a justifiable topic to investigate as there seems to be a dearth of locally conducted research on the topic.

The research findings from the aforementioned research projects were mostly obtained through quantitative research. Green (1996) confirms this and further states that these research endeavours are exclusively based on adult gay/lesbian children's retrospective accounts of how parents experienced their coming out. He goes on to say that there is a need for parents (and siblings) to give their own retrospective accounts of how they experienced the coming out of a child (or sibling).

Green (1996) further stresses the fact that, in the light of the correlational rather that the longitudinal nature of the research done, we must conclude that the short-term or long-term consequences of a gay/lesbian child's coming out to parents, and the parent-child relationship, remain relatively unknown at this stage. From this the researchers conclude that there is a need for qualitative research into the experiences of parents as they relate to the coming-out process of a gay/lesbian child. Butler (2000:549) confirms this need for more qualitative-orientated research.

Based on the introduction and problem formulation, the following problem statement was postulated in respect of this research endeavour: Because of the sparse amount of qualitative indigenous knowledge relating directly to the experiences of parents in terms of their realisation that they have a gay/lesbian child, it is vital, within the ambit of social work and in general, that qualitative research be conducted in this particular area.

\section{RESEARCH QUESTION AND GOAL}

One typically finds research questions, not hypotheses, written into qualitative studies (Creswell, 1994:70). In confirmation, Fossey, Harvey, McDermott and Davidson (2002:723) state that "relatively broad questions, rather than specific hypotheses to be tested, identify the initial focus of the inquiry". Research questions, aims/goals and objectives become signposts for explaining the purpose of the study and guiding the research. The question formulated at the outset of this study was the following: "What are the experiences of parents regarding the coming-out process of their homosexual child?" 
In guiding the process of answering this research question, the following goal was formulated: "To explore and describe parents' experiences relating to the coming-out process of their gay/lesbian child".

\section{RESEARCH APPROACH AND METHODOLOGY}

In view of the recommendations by Butler (2000:549) and Green (1996:399) for more qualitative-orientated research where parents give their own retrospective accounts of how they experienced the coming out of a gay/lesbian child, the researchers opted for a qualitative research approach. According to Fossey et al. (2002:717), “...qualitative research is a broad umbrella term for research methodologies that explore, describe and explain persons' experiences, behaviours, interactions and social contexts without the use of statistical procedures or quantification." The qualitative paradigm appeared to be the appropriate choice, because it aided the researchers in their quest to obtain subjective, personal data pertaining to the experiences of parents relating to the coming out of a gay/lesbian child. This approach afforded the parents, as self-knowing subjects, the opportunity to speak authoritatively about the situation being studied.

Within the qualitative approach the researchers employed a phenomenological, explorative, descriptive and contextual research design or strategy of inquiry. Phenomenology, according to Crabtree and Miller (1999:25), "...seeks to understand the lived experience of individuals and their intentions within their 'lifeworld'. It is the search for essences. It answers the questions, 'What is it like to have a certain experience?' 'What is the essence of this particular experience?"' The researchers wanted to explore what the experiences of parents were in relation to the coming out of their gay/lesbian offspring. In view of the fact that there seems to be a dearth of indigenous qualitative-generated research on the topic, the researchers employed an explorative research design. Neuman (1997:17) notes that the explorative mode of inquiry is used to explore a new topic or learn more about issues where little is known. The descriptive design was employed to provide a detailed description of what was explored (Neuman, 1997:20). The contextual design was used as the researchers wanted to investigate a phenomenon in a specific context (i.e. the experiences of parents in the context and as a result of their gay/lesbian child's coming-out process).

A non-probability sampling technique, namely purposive sampling, was employed as the researchers sought participants who were information-rich because of their knowledge and ability to describe the phenomenon under study (Donalek \& Soldwisch, 2004:356). The researcher responsible for the fieldwork approached gatekeepers (i.e. fellow colleagues) and provided information for writers of feature articles to be published in newspapers to get in contact with potential participants. Some of the individuals who participated in the study referred her to other participants who willingly participated in the study. Customary to qualitative research, no sample size was determined at the outset of the study, but the principle of "saturation of data" determined the sample size. The field worker continued with the collection of data from multiple participants until the themes emerging from the data became fully developed and repetitive (Fossey et al., 2002:72; Donalek \& Soldwisch, 2004:356). After this the researchers engaged in a consensus discussion and decided that the data have reached a point of saturation and the process of data collection could be concluded. Only participants who met the following criteria were included in the study: 
- participants who resided in the Nelson Mandela Metropole;

- participants with a gay or lesbian child who has revealed their sexual identity to the participants;

- participants who were available and willing to participate in the study, in that they were fully aware of what the study entailed and participated of their own free will.

Interviewing, focus groups and participant observation are common modes of qualitative data gathering (Fossey et al., 2002:72). Data were collected by means of semi-structured interviews with the aid of an interview guide. Holloway and Wheeler (1996:55) and Kvale (1996:174) explain that semi-structured or focused interviews use questions that are contained in an interview guide (not a schedule, as in quantitative research) with the focus on themes or issues to be covered. The following request and questions formed part of the interview guide:

Request: Can you tell me more about your experiences with regard to the coming-out process of your (gay/lesbian) child?

Questions: (1) What feelings did you experience in the process of your child coming out with his/her homosexual identity?

(2) What hindered you in this process?

(3) What helped you cope in this process?

(4) What advice would you give other parents in similar situations?

With the consent of the participants, all the interviews were audio-taped. On completion of the data-collection process, the process of data analysis commenced. Creswell (1994:153) contends that the researcher is engaged in several activities during qualitative data analysis. These include collecting the data, transcribing the interviews, sorting the data into categories, formatting the data into a coherent story or picture, and writing the qualitative text. This study employed the eight steps provided by Tesch (in Creswell, 1994:155) to analyse the data systematically, by segmenting it into words or categories that subsequently formed the basis of the emerging story or picture.

For the purpose of data verification, the researchers followed Guba's model of trustworthiness (in Krefting, 1991:215-222), which identifies four criteria and strategies for ensuring and establishing trustworthiness, and which are therefore used to assess the qualitative research process undertaken.

- The first criterion addressed in establishing trustworthiness is that of truth value, that is, determining to what extent the findings are a true reflection of the "life-worlds" of the participants, as experienced and described by them. The strategy for establishing truth value is credibility. The particular actions taken to achieve credibility included triangulation (that is, triangulation of data sources, interviewing multiple participants and the triangulation of different investigators involved in this research project), peer examination, interviewing techniques, and the authority of the researcher conducting the fieldwork.

- The second criterion is applicability, or the degree to which findings can be applied to other contexts or settings and groups (that is, generalisability). Transferability was the strategy employed to attain applicability. Two perspectives of applicability for qualitative research have been delineated (Krefting, 1991:216). The first perspective holds that applicability is not seen as being relevant to qualitative research, as it proposes to describe experiences or phenomena which cannot be generalised to other experiences or phenomena (Krefting, 1991:216). The second perspective proposed by Guba in Krefting (1991:216), however, 
claims that fittingness is the criterion against which applicability of qualitative research can be assessed. If the findings of a study fit into contexts outside the study situation by means of similarity and goodness-of-fit between the two contexts, then transferability has been achieved. In this study transferability was achieved by documenting "dense" descriptions of the research methodology and by working contextually, so that procedures could be duplicated accurately.

- The third criterion of Guba's model (in Krefting, 1991:215-222) is termed consistency, which is concerned with the extent to which the replication of the study in a similar context or with similar informants will produce the same results. Dependability was the strategy used to ensure consistency. The actions that were taken to ensure dependability in this study included peer examination of the research methodology and implementation, triangulation of data sources and investigators, a dense description of the research methodology, independent coding and the implementation of a code-recode procedure (Krefting, 1991:216-217).

- Neutrality is the fourth and final criterion, and refers to the extent to which the study's findings are free from bias. Lincoln and Guba in Krefting (1991:217) propose that neutrality in qualitative research should consider the neutrality of the data rather than that of the researcher, and thus suggested confirmability as the strategy to achieve neutrality. In this study triangulation was employed to achieve confirmability (Krefting, 1991:221-222).

\section{DISCUSSION OF FINDINGS}

The research findings presented in the ensuing part of this paper resulted from the analysis of the 13 in-depth semi-structured interviews conducted with the parents of a gay/lesbian child, and a consensus discussion on the analysed data between the researchers and the independent coder.

The discussion on the research findings will be presented in two sections, namely:

- a biographical profile of the participants; and

- a discussion on the themes, sub-themes and categories that emerged from the process of data analysis and the consensus discussion. Each of these will be supported by narratives from the transcribed interviews and further complemented by a literature control.

\section{A BIOGRAPHICAL PROFILE OF THE RESEARCH PARTICIPANTS}

Table 1 provides a biographical profile of the sample group.

When focusing on Table 1 it becomes clear that the majority of the participants were mothers and were white persons. Except for one participant, the rest of the participants' ages range from 43 to 68 years. According to Thomas (1992:150-152), individuals in this age range fall in the middle, later middle and older adulthood life-cycle stages. In relation to the coming out of children of mature or elderly parents, Savin-Williams (1989:3-4) states the following: "Elderly parents may have more difficulty accepting their child's homosexuality because of the social and political climate of their childbearing years when homosexuality was viewed as an unspeakable, moral sin or a deep psychological pathology". 
TABLE 1

BIOGRAPHICAL PROFILE OF SAMPLE GROUP

\begin{tabular}{|c|l|c|c|c|c|c|c|}
\hline $\begin{array}{c}\text { Partici- } \\
\text { pant } \\
\text { Code }\end{array}$ & $\begin{array}{l}\text { Gender of parent } \\
\text { interview } \\
\text { conducted with }\end{array}$ & Age of \\
mother & $\begin{array}{c}\text { Age of } \\
\text { father }\end{array}$ & Race & $\begin{array}{c}\text { Number } \\
\text { of } \\
\text { children } \\
\text { in the } \\
\text { family }\end{array}$ & $\begin{array}{c}\text { Number of } \\
\text { homosexual } \\
\text { children in the } \\
\text { family }\end{array}$ & $\begin{array}{c}\text { Gender of the } \\
\text { homosexual } \\
\text { child }\end{array}$ \\
\hline E & Mother & 57 & 61 & White & 3 & 2 & Male \\
\hline H & $\begin{array}{l}\text { Both mother and } \\
\text { father }\end{array}$ & 63 & 64 & White & 3 & 1 & Female \\
\hline J & Mother & 43 & 52 & White & 2 & 1 & Male \\
\hline M & Adoptive mother & 53 & 66 & White & 1 & 1 & Female \\
\hline L & Mother & 66 & 68 & White & 2 & 1 & Male \\
\hline P & Mother & 57 & 57 & White & 2 & 1 & Female \\
\hline C & Mother & 46 & 48 & White & 3 & 1 & Male \\
\hline S & $\begin{array}{l}\text { Both mother and } \\
\text { father }\end{array}$ & 68 & 67 & White & 2 & 1 & Male \\
\hline D & Mother & 51 & 57 & White & 4 & 1 & Male \\
\hline Y & Mother & 66 & Deceased & White & 2 & 1 & Male \\
\hline X & Mother & 36 & - & Black & 2 & 1 & Male \\
\hline U & Mother & 48 & 48 & Coloured & 7 & 1 & Male \\
\hline R & $\begin{array}{l}\text { Sister-in-law } \\
\text { (Custodian) }\end{array}$ & 45 & - & Coloured & 3 & 1 & Male \\
\hline
\end{tabular}

\section{THEMES, SUB-THEMES AND CATEGORIES (WHERE APPLICABLE): A THEMATIC DISCUSSION}

The responses from the participants resulted in the following five themes with accompanying sub-themes:

- Experiences of parents regarding the coming-out process. This theme was divided into the following sub-themes: experiences of loss and of relief.

- Feelings experienced by parents following the child's coming out. The former were divided into the following sub-themes: feelings of shock, disappointment, embarrassment, fear, guilt, sadness and hurt, and feelings of relief and happiness.

- Reactions of parents after the coming out of a gay or lesbian child. These were divided into the following sub-themes: shock and denial, anger, bargaining, depression and sadness and acceptance.

- Factors that helped and complicated the process in accepting their child's homosexual identity.

- Advice offered to parents regarding coping with a child's coming out.

Each of these themes with their accompanying sub-themes and categories (where applicable) will be discussed in the remainder of this article and will be subjected to a literature control.

\section{THEME 1: EXPERIENCES OF PARENTS REGARDING THE COMING-OUT PROCESS}

This theme was divided into the following sub-themes: experiences of loss and of relief.

The following three excerpts from the transcripts speak about the loss experienced by the parents consequent to the coming out of their gay/lesbian child: 
"Um, it seems as if there was a dreadful death in the family and the emptiness, the loss, it's definitely there. All of a sudden your world has been destroyed. What I mean by that is normally you have ideas of a wedding, a son-in-law, and grandchildren and now there is just plain nothing." Literature confirms that the loss experienced by parents when a child comes out can be equated to a death in the family (Fields, 2001).

"So you have these ideals in life, and then suddenly you don't get them."

In one of the interviews with both the husband and the wife, the husband said: "...you have lost a dream. It was your dream that has died. It is not something that John [pseudonym] wanted to happen to him, it is not something that was in the plan. It's something that you have built up. You have built up this thing of John being married one day and having all these grandchildren and ..." His wife continued by saying: "I think he crushed all my plans that I had, [wanting him to] get married, having grandchildren, I wondered how the wedding was going to be and then he came and slapped this one on me." In confirming the loss of ideals and dreams parents have for child when he/she comes out, Du Plessis (1999:1) states: "Alle ouers het drome en ideale vir hul kinders. Hierdie sluit gewoonlik 'n gelukkige huwelik en etlike kleinkinders in. Konfrontasie met die feit dat jou kind homoseksueel is, is gewoonlik, selfs vir die mees begrypende en aanvaardende ouer, aanvanklik 'n groot teleurstelling, Dit beteken dat hulle drome en ideale drasties gewysig moet word om by die nuwe realiteit aan te pas."

Experiences of relief were felt by most of the participants consequent to being informed about their child's homosexual orientation. It took a huge burden off their shoulders in that they felt that they were in touch with what had been going on and were no longer in the dark. Quotations in support of this sub-theme are:

"Experiences of relief that it was all out."

"But to me it was a big relief when he wrote us a letter and said 'but this is it' and a letter to his brother and said: 'That's how I am.' It was a turning point in understanding and learning how to 'cope' if that is the right word."

\section{THEME 2: FEELINGS EXPERIENCED BY PARENTS FOLLOWING THE CHILD'S COMING OUT}

All the participants seemed to have responded with shock to their children making their homosexual orientation public. The following excerpts from the transcripts attest to this:

"... and of course it is a terrible shock firstly."

"We were just devastated. Well, the first time I was told, my husband told me. It was a terrible shock, I was devastated." These feelings of devastation experienced by parents following the coming out of a child are confirmed by Ben-Ari (1995a:107), Savin-Williams (1989:3), and Warren and Wiedenkeller (1993).

"I must say I was quite stunned and upset. It was very hard to accept." Joubert (1998:19) echoes these feelings of being upset when a child outs as gay/lesbian and states: "...natuurlik was ons hewig ontsteld daaroor ... dat [ons] seun werklik nie "meisies kan liefhê nie"". In Saltzburg's (2007:62) research there was a consensus amongst the parents regarding feeling "stunned" by the actual disclosure of their child's homosexuality.

Some participants experienced feelings of disappointment following the coming out of their children. Storylines to confirm this sub-theme are:

"Disappointment, a lot of disappointment." 
"...I suppose disappointment, you know, it's very difficult the whole thing. How are you going to live with this? How are you going to tell you friends?" The quotation by Du Plessis (1999:1) (provided above) confirms this feeling of disappointment experienced by the parents subsequent to their children's coming out.

The feelings of embarrassment experienced by the participants were encapsulated in the following utterances:

"Embarrassment when she's in public [and showing her affection to her partner] ...I think that's natural although we have accepted it generally there are still that that make you feel uncomfortable especially in public."

"I get embarrassed, I mean we have been out to dinner with her and I get embarrassed if she puts her arm around her friend... when you see other people looking at you..."

In Warren and Wiedenkeller's (1993) research a farther stated that for a long time he felt ashamed about the fact that his son is gay.

Participants mentioned that they had experienced feelings of fear in a wide variety of contexts and situations. This will be indicated as categories in the table below and supported by excerpts from the transcriptions to underscore each category and where possible literature to confirm the research finding will be indicated.

\section{TABLE 2}

\section{FEELINGS OF FEAR EXPERIENCED IN VARIOUS CONTEXT AND SITUATIONS RELATING TO THE COMING OUT OF A GAY/LESBIAN CHILD}

\begin{tabular}{|l|l|l|l|}
\hline \multicolumn{2}{|c|}{ Categories } & \multicolumn{1}{c|}{ Excerpts from the interviews } \\
\hline 1 & $\begin{array}{l}\text { Fearing the reaction } \\
\text { of other parents } \\
\text { when they find out } \\
\text { that a person's child } \\
\text { is homosexual }\end{array}$ & $\begin{array}{l}\text { to approach them because you don't know what their reaction is going to } \\
\text { be." This articulated fear is confirmed by Woog (1997): "Besides the shock, } \\
\text { guilt and shame, they worry about and fear what the family and friends will } \\
\text { think about them and their child. Those feelings are strong even with all the } \\
\text { support available." }\end{array}$ \\
\hline 2 & $\begin{array}{l}\text { Fear by the one } \\
\text { parent that the other } \\
\text { parent might reject } \\
\text { the child because of } \\
\text { his/her homo-sexua- } \\
\text { lity }\end{array}$ & $\begin{array}{l}\text { This fear is articulated by a participant in Warren and Wiedenkeller's (1993) } \\
\text { research when she said to her gay son: "It is not a problem for me, and I } \\
\text { know it's okay with God, but I don't know what we are going to do about } \\
\text { to this category as follows: “...the father of the child will not support the } \\
\text { child or will have nothing to do with us [her and the child] until the child } \\
\text { changes." }\end{array}$ \\
\hline 3 & $\begin{array}{l}\text { Fear of the fact that } \\
\text { the child might have } \\
\text { an unsettled life }\end{array}$ & $\begin{array}{l}\text { "Um, just knowing that life [as a gay person] would be difficult for him." } \\
\text { unsettled life." These fears verbalised by the participants were similar to } \\
\text { some of the concern for the participants (parents) in Ben-Ari's (1995a:103) } \\
\text { research. }\end{array}$ \\
\hline 4 & $\begin{array}{l}\text { Fear that they will } \\
\text { not be able to break } \\
\text { the news to others } \\
\text { about their child's } \\
\text { homosexuality }\end{array}$ & $\begin{array}{l}\text { "...how am I going to explain to other people, you know, my son is gay?" } \\
\text { "Telling my friends and my family [about her daughter being a lesbian] was } \\
\text { a terrible thought. I was scared that they would reject my loveable child, and } \\
\text { even me." }\end{array}$ \\
\hline
\end{tabular}




\begin{tabular}{|c|c|c|}
\hline \multicolumn{2}{|r|}{ Categories } & Excerpts from the interviews \\
\hline 5 & $\begin{array}{l}\text { Fear that they will } \\
\text { not be able to } \\
\text { handle the situation } \\
\text { when the child } \\
\text { brings a partner } \\
\text { home }\end{array}$ & $\begin{array}{l}\text { "I began to fear how I am going to react in a situation when he is going to } \\
\text { bring someone home." This fear is confirmed by one of the participants in } \\
\text { Warren and Wiedenkeller's (1993) research in the following excerpt: "I was } \\
\text { shocked when I saw him kissing, hugging and holding hands. I guess I knew } \\
\text { they did it, but I couldn't get comfortable with it." }\end{array}$ \\
\hline 6 & $\begin{array}{l}\text { Fear of the reaction } \\
\text { when people see the } \\
\text { child and his/her } \\
\text { lover }\end{array}$ & $\begin{array}{l}\text { "But I am still scared of what is going to happen ... when people see him } \\
\text { and the other one together. How are people going to react?" A similar fear } \\
\text { was indicated by } 43 \% \text { of the } 27 \text { parents participating in the study conducted } \\
\text { by Ben-Ari (1995a:110). }\end{array}$ \\
\hline 7 & $\begin{array}{l}\text { Fear that the child } \\
\text { might die of AIDS }\end{array}$ & $\begin{array}{l}\text { "The first thing that went through my mind was, 'my God this child is going } \\
\text { to die of AIDS or something.' Cause I mean that is what I related with gay, } \\
\text { 'AIDS'." } \\
\text { "I thought [and feared] he was going to die of AIDS." Participants in both } \\
\text { Woog's (1997) and Ben-Ari's (1995a:103) research were also concerned, or } \\
\text { feared, the fact that their children might contract the HI virus and eventually } \\
\text { die of AIDS. }\end{array}$ \\
\hline 8 & $\begin{array}{l}\text { Fear of the fact that } \\
\text { the child might be } \\
\text { lonely and rejected }\end{array}$ & $\begin{array}{l}\text { "You know I always thought gay people are very lonely people; they are } \\
\text { always rejected; they don't have family." Warren and Wiedenkeller (1993) } \\
\text { confirm this by stating: "gay youth ... often feel totally alone and socially } \\
\text { withdrawn out of fear of adverse consequences." }\end{array}$ \\
\hline 9 & $\begin{array}{l}\text { Fear of the reaction } \\
\text { of the siblings } \\
\text { toward the brother/- } \\
\text { sister's homosexua- } \\
\text { lity }\end{array}$ & $\begin{array}{l}\text { "My biggest issue is losing my child, on the other side telling my other son } \\
\text { [about his brother being gay] and losing him too." Borhek (1988:126) notes } \\
\text { that an individual's coming-out process involves siblings, as well as parents } \\
\text { and that the reaction of the former to a brother/sister's coming out may be } \\
\text { unpredictable. In the light of this, this participant's fear is not unfounded. }\end{array}$ \\
\hline 10 & $\begin{array}{l}\text { Fear that the child } \\
\text { will be hurt }\end{array}$ & $\begin{array}{l}\text { "There is definitely still fear. But I think not fear about what people are } \\
\text { going to say, but how he's going to feel ... when somebody goes by and } \\
\text { says: 'jou donnerse moffie'. I fear how it is going to hurt his feelings. } \\
\text { "[I fear him getting hurt, because] for me the homosexual world is a cruel } \\
\text { world." }\end{array}$ \\
\hline 11 & $\begin{array}{l}\text { Fear of the stigma - } \\
\text { "What will people } \\
\text { say?" }\end{array}$ & $\begin{array}{l}\text { "The stigma is terrible and then you have people call them 'moffies', you } \\
\text { know, that type of thing is terrible." } \\
\text { "The stigma is a big factor... you feel that people are laughing behind your } \\
\text { back, sort of thing..." }\end{array}$ \\
\hline
\end{tabular}

After their children expressed their homosexual orientation, some participants experienced feelings of guilt as demonstrated by the following utterances:

"...I had guilt feelings, I did say to the minister what did I do wrong? Where did I go wrong? He said, 'no, if you have two of them, they grew up in the same home, the one is gay and the other isn't, then it can't be you'."

"Um, that I was to blame. You immediately think that it is your fault, which it is something that you did wrong."

Both Armesto (2001) and Woog (1997) state that parents often experience feelings of guilt and shame as a result of a child's disclosure that he/she is gay/lesbian. 
Some of the participants experienced feelings of hurt and sadness following the coming out of their gay/lesbian child. The following utterances refer to this:

"At the time I was angry, I felt sad, very sad, it affected my prayers, it affected me as a Christian."

"And then you sort of feel sorry for the guy because it is difficult in the work place. It is difficult to start saying that you are gay ... you are different than most people, so it is jolly difficult, so you feel sorry for them."

Feelings of fear and relief were also experienced in terms of the fact that the facts about their child's homosexuality were now in the open. The following to statements underscore this:

"Relief, because now there didn't appear to be an obstacle. When one thinks back there was this barrier, which had now been removed because he had been honest with us."

"... I am so glad that he discovered that he was that way inclined and that he didn't first get married and then wreck somebody else's life ... have kids and then leave..."

\section{THEME 3: REACTIONS OF PARENTS AFTER THE COMING OUT OF A GAY OR LESBIAN CHILD}

From their accounts it was noted that their offspring's coming out propelled the participants into a state of grieving where they grieved the loss of a child's heterosexual identity. Most mothers and fathers assume that their children will grow up to be heterosexual, and when they learn otherwise they experience feelings of profound loss. Dreams of weddings and grandchildren that hinge on heterosexuality are shattered (LaSala, 2000). As a result LaSala (2000) postulates that parents of gay/lesbian children experience Kübler-Ross's five grieving stages, beginning with shock, moving through denial, sadness and anger to eventual acceptance of their children's sexual orientation (Ben-Ari, 1995b:308). This observation by LaSala (2000) was confirmed in this study as the participants initially reacted with shock to the news that their child was gay or lesbian. These shock reactions and/or experiences were alluded to and discussed in the previous theme. Apart from the shock reactions, the participants also went into denial and withdrew themselves. The following storylines bear testimony to this:

"In the beginning it takes quite a while ...you still hope and think maybe it's a passing phase or something."

"Cause I mean that [denial] is your first reaction to try and tell them no they are just being stupid, they must come right."

"Well I went through quite dramatic feelings in the beginning ... it was a very private thing we never discuss with friends."

"I think it is because you felt you were trying to hide something you weren't being open with your friends... there are some very close friend that I just felt that I couldn't say, 'well you know my daughter is gay'.”

"I never went to the shops, I never walked out of my front door for three months, and I could not face the world." Denial is described as the response of an individual to avoid disagreeable realities by ignoring or refusing to acknowledge them. It is a defence mechanism in which an individual refuses to acknowledge a painful or threatening reality (Hamachek, 1992:44; Morris, 1996:449). The denial and withdrawal displayed by the participants consequent to the coming out of their gay/lesbian child is confirmed by Warren and Wiedenkeller (1993), who state that too many parents go into the closet when their children come out of it. 
Anger as a common feature in response to loss was also experienced by the participants and was directed towards self and others. The anger towards self mainly manifested in self-blame. The following storylines refer to this:

"How did it happen? First I blamed myself because when he was born I wanted a little girl because it would have been the first granddaughter in the family but it wasn't an obsession."

“... you immediately think that it is your fault that it's something that you did wrong."

"Where did I go wrong...?"

Apart from the self-blame, participants also blamed others as the following utterance illustrate: "So there was this self-blame, and blaming everyone else, I also blamed God, well actually, I was too scared to blame Him but it was there."

The anger towards others was mainly directed towards their gay/lesbian child. Storylines confirming this are:

"I was cross at first and disgusted, because I never expected it from him."

"I felt very angry, very angry at that moment in time ... I felt like the child was deceiving us well deceiving me. I wasn't let in on this whole thing." Parents feeling angry and reacting with anger following the coming-out of a child is also noted in the research of Ben-Ari (1995a:93) and LaSala (2000).

Some of the participants tried to bargain with their gay/lesbian children in the hope that they might change. The following quotations are provided in support of this:

"We are a Christian family, we sat with the Bible with him and took verses out of the Bible showing him that this is Biblically wrong and it is not acceptable..."

“I asked him again, 'don't you want to go to a psychologist' and he said, 'all right....." One of the participants in Warren and Wiedenkeller's (1993) research underwrites the fact that parents tried to bargain with him following his coming out and states: "When I finally told my parents last year, they tried to bargain with me. They sent me to a shrink, but I finally said, 'This is the way I am. I would change if I could, but I can't'".

A common side effect of the grieving process is depression and sadness. Utterances made by the participants in Saltzburg's (2007:62-63) research confirms participants' depression and sadness resulting from the process of mourning the loss of their children's heterosexual identity. In this research study the participants pointed to the fact that the coming out of their gay/lesbian children saddened them and they reacted to this by crying. The following quotes are proof of this:

“...I think I just cried ... was emotional for a very long time."

"I just cried the whole day, I couldn't get over it."

Acceptance is the final phase in the grieving process and it entails a realisation that the inevitable is here to stay. According to Joubert (1998:102), acceptance will only become a reality when a person starts to realise that it is not the circumstances that control him/her, but rather his/her attitude towards the situation. To come to accept a child's homosexual identity Ben-Ari (1995a:107) suggests that it would be useful to consider the difference between "acknowledgement" and "acceptance". He explains: "While 'acknowledgement' refers to the recognition of a fact, 'acceptance' refers to a different kind of recognition. It is more than just recognition of a fact; 'acceptance' includes an affective component. One can acknowledge a 
fact without accepting it, but not vice versa. In that respect, acknowledgement is a precondition for acceptance." Therefore, parents would have to acknowledge the fact that their child is gay/lesbian before they could fully accept this.

The following storylines testify to the fact that some of the participants in this study have not only acknowledged their children's homosexual identity, but also accepted it:

"Well I just felt, it's a decision that could not be changed. She could not change it. We could not change it. We had to support her and accept that she was our child and that was it. We just had to accept it."

"... I mean we have come a long way now and we have accepted it and we support her for ..."

"I have dealt with all - there is no festering, anger, animosity, hatred, repulsion, nothing ..."

From the utterances of the participants it can be concluded that the parents are at different "stages" on their journey of acceptance of their children's homosexuality. Miller (in Ben-Ari, 1995a:108) found that parents who become "stuck" in one of the stages of grief cannot move beyond it and will not reach the destination of acceptance. With reference to the time it takes to accept a child's homosexual identity, Hansen (in Woog, 1997) speculates as follows: "For most parents, the journey to acceptance takes five to ten years. They cycle around it. They get easier with it", and ultimately acceptance will dawn as echoed by the following participant: "... it was difficult to accept at first and now thinking back it was gradual acceptance. We didn't accept is as such from day one. We still thought 'you are wrong, you are not a homosexual', I can't believe it, not my son, no where did we go wrong, did we make a sissy out of him?"

One participant mentioned that accepting the child's homosexuality led to a closer parent-child relationship, "It has drawn us even more closely together and that is very nice for me." The positive outcome of the child's coming out on the parent-child relationship is also documented in the literature (Cramer \& Roach, 1988:87; Woog, 1997).

\section{THEME 4: FACTORS THAT HELPED AND COMPLICATED THE PROCESS IN ACCEPTING THEIR CHILD'S HOMOSEXUAL IDENTITY}

This theme will be divided in two sub-themes and the categories inherent to each will be presented in table format.

\section{Sub-theme: Factors that helped parents to accept their child's homosexuality}

The factors that helped parents to accept their child's homosexuality will be indicated as categories in the table below and supported by excerpts from the transcriptions to underscore each category and where possible literature to confirm the research findings will be indicated. 
TABLE 3

FACTORS THAT HELPED PARENTS TO ACCEPT THEIR CHILD'S HOMOSEXUALITY

\begin{tabular}{|c|c|c|}
\hline \multicolumn{2}{|r|}{ Categories } & Excerpts from the interviews \\
\hline 1 & $\begin{array}{l}\text { Reframe child's homo- } \\
\text { sexuality as God's plan to } \\
\text { support him }\end{array}$ & $\begin{array}{l}\text { "I suppose, God has put this child in our family because He knows } \\
\text { we won't throw him out. We will stand by him and see him through } \\
\text { it." }\end{array}$ \\
\hline 2 & $\begin{array}{l}\text { Reframe child's homo- } \\
\text { sexuality as something God } \\
\text { wanted him/her to have }\end{array}$ & $\begin{array}{l}\text { "Well that was really a shock to know that they were both like that } \\
\text { [both the participant's sons are gay]. It was a shock and I just to } \\
\text { this day can't tell why. It's probably how God wanted them to } \\
\text { be..." }\end{array}$ \\
\hline 3 & $\begin{array}{l}\text { Accept the child's homo- } \\
\text { sexual orientation or face } \\
\text { losing him/her }\end{array}$ & $\begin{array}{l}\text { "Number one reason for accepting it; if you don't accept it, you } \\
\text { lose a child." }\end{array}$ \\
\hline 4 & choice to be ga & $\begin{array}{l}\text { "I found out that all the counsellors believe that it's not a choice } \\
\text { thing. Homosexuality is not a thing you choose. They all felt that } \\
\text { you are born like that and there are various reasons for it. The } \\
\text { person can't help being like that. Warren and Wiedenkeller (1993) } \\
\text { agree with this and state: "Homosexuals do not choose their sexual } \\
\text { orientation." }\end{array}$ \\
\hline 5 & $\begin{array}{l}\text { The realisation that there } \\
\text { are many gay people and } \\
\text { parents with gay children }\end{array}$ & $\begin{array}{l}\text { "It [referring to knowing there are other parents with gay/lesbian } \\
\text { children too] sort of helped you and you realise that you are not } \\
\text { the only person going through this." }\end{array}$ \\
\hline 6 & $\begin{array}{l}\text { Reading about homo- } \\
\text { sexuality and how parents } \\
\text { with a homosexual child } \\
\text { coped }\end{array}$ & $\begin{array}{l}\text { "But I would say reading that book really helped." } \\
\text { "The books he [her gay son] bought me ... A lot of my questions } \\
\text { were answered when I read them." Borhek (1988:126) supports the } \\
\text { idea that gay/lesbian children present their parents with books on } \\
\text { homosexuality once they have made their homosexual identity } \\
\text { public. Warren and Wiedenkeller (1993) advise that parents who } \\
\text { suspect their child to be gay/lesbian should educate themselves on } \\
\text { the topic. }\end{array}$ \\
\hline 7 & $\begin{array}{l}\text { Realisation that the child is } \\
\text { happy }\end{array}$ & $\begin{array}{l}\text { "...It made it easier for me [to accept] because he was happy, he } \\
\text { looked happier. He was a terribly moody boy ... and then he } \\
\text { changed and was more himself, happy..." }\end{array}$ \\
\hline 8 & $\begin{array}{l}\text { Accepting the child's } \\
\text { homosexual identity }\end{array}$ & $\begin{array}{l}\text { "I am happy with it [her son being gay]. I fought with it for a long } \\
\text { time but I know now there is nothing I can do. If I am going to } \\
\text { fight this and be against it, I am going to chase my child away." }\end{array}$ \\
\hline 9 & $\begin{array}{l}\text { Suspicions for some time } \\
\text { that the child might be gay }\end{array}$ & $\begin{array}{l}\text { "Well not quite shock or maybe shock at the confirmation of what } \\
\text { we might have suspected... From time to time, although we [him } \\
\text { and his wife] never discussed it, we thought that he might be that } \\
\text { way inclined ... we had it in the back of our minds." }\end{array}$ \\
\hline
\end{tabular}

The above exposition on how the participants went about embracing their children's homosexual identities fits within a resilience framework. Oswald (in Ganong \& Coleman, 2002:347) has examined and identified the elements that may contribute to resilience in gay 
and lesbian families and found two elements of resilience to be of significance also for parents with a gay/lesbian child, namely redefinition of the situation and strategies by people to validate themselves and strengthen their ties to supportive others. Resilience, according to Ganong and Coleman (2002:347), can be defined as "...a process by which individuals, relationships, and families adapt to contexts of significant adversity ... [it is] a mindset of 'changing the odds' ...in contrast to ... the prevailing emphasis on ... 'beating the odds' through their own strengths and abilities." The participants used the strategy of "redefining", sometimes also called "relabelling" or "reframing" to change the meaning they assigned to the coming-out process of their gay/lesbian child in order to embrace his/her homosexual identity.

The participants also mentioned the following sources of support that helped them with coming to terms with their child's homosexual identity: (1) support from professionals (i.e. minister and psychologists); (2) support from the husband; (3) support from the gay/lesbian child; (4) support from other relatives (i.e. a brother, parents); (5) support from friends; (6) support from the gay/lesbian child's friend and his/her lover/partner. The literature consulted also refers to the sources of support identified by the participants. Clarke (1987:13), in referring to family and friends as sources of support, remarks: "Remember that you are much more certain to survive and grow with a little help from your family and friends". Borhek (1988:12) advises that in order for parents to come to terms with their child's homosexual identity, the latter must become "a parent to their parents".

Sub-theme: Factors that complicated the process for parents in accepting their child's homosexuality

The factors that complicated the process for parents in accepting their child's homosexuality will be indicated as categories in the table below and supported by excerpts from the transcriptions to underscore each category; where possible, literature to confirm the research findings will be indicated.

\section{TABLE 4}

\section{FACTORS THAT COMPLICATED THE PROCESS FOR PARENTS IN ACCEPTING} THEIR CHILD'S HOMOSEXUALITY

\begin{tabular}{|l|l|l|}
\hline 1 & $\begin{array}{l}\text { Fear of the stigma attached } \\
\text { to having a homosexual child }\end{array}$ & $\begin{array}{l}\text { "I think the stigma was possibly a difficult thing to overcome." } \\
\text { Woog (1997) confirms this and states: "Besides the shock, guilt } \\
\text { and shame, they worry about what their family and friends will } \\
\text { think of them and their child." }\end{array}$ \\
\hline 2 & $\begin{array}{l}\text { Fear of being rejected by } \\
\text { friends. }\end{array}$ & $\begin{array}{l}\text { "...it's just that it is frowned upon and it is not really acceptable } \\
\text { amongst our friend and church." Borhek (1988:125) notes that } \\
\text { parents fear that they may lose some or all of their friends because } \\
\text { of the issue of their child's sexual orientation. }\end{array}$ \\
\hline 3 & $\begin{array}{l}\text { Fear that their child will } \\
\text { show his/her affection to } \\
\text { partner in public }\end{array}$ & $\begin{array}{l}\text { "I get embarrassed, I mean we have been out to dinner with her } \\
\text { and I get embarrassed if she puts her arm around her friend... } \\
\text { when you see other people looking at you..." In Warren and } \\
\text { Wiedenkeller's (1993) research a farther stated that for a long time } \\
\text { he felt ashamed about the fact that his son is gay. }\end{array}$ \\
\hline 4 & $\begin{array}{l}\text { Fear of reaction from close } \\
\text { family members }\end{array}$ & $\begin{array}{l}\text { "Well because we thought ...they would think less of him. My mom } \\
\text { dies not knowing, she loved her grandchildren and I think her } \\
\text { whole attitude towards him would have changed has she known he } \\
\text { was gay" (Repsold, in Germond \& De Grunchy, 1997:23). }\end{array}$ \\
\hline
\end{tabular}




\begin{tabular}{|c|c|c|}
\hline 5 & $\begin{array}{l}\text { The church's stance on } \\
\text { homosexuality }\end{array}$ & $\begin{array}{l}\text { "I think again for me I felt sad that he was living a life that was } \\
\text { against what the church teaches." } \\
\text { "There is so much in the Bible when one knows where to look for } \\
\text { it about homosexuality and how it condemns homosexuals. [They] } \\
\text { have been dumped with murders, rapists, and prostitutes and so } \\
\text { forth..." Kay (1997:86) states that if the church adopts a } \\
\text { condemning stance towards homosexuality, Christian parents tend } \\
\text { to treat the child as an outcast. }\end{array}$ \\
\hline 6 & $\begin{array}{l}\text { Parents' own beliefs about } \\
\text { homosexuality }\end{array}$ & $\begin{array}{l}\text { ".. at that time [referring to the time soon after their child came } \\
\text { out to them] we thought along the lines most people thought-we } \\
\text { don't like gays. They want nothing to do with gays, they are } \\
\text { disgusting - an abomination. They must be pushed to one side and } \\
\text { [we must] have nothing to do with them." Ben-Ari (1995a:105) } \\
\text { associates difficult post-discovery family dynamics with parents } \\
\text { who had no previous experience with anything remotely related to } \\
\text { homosexuality. Furthermore, they harboured negative beliefs } \\
\text { about it and were less likely to register acknowledgement and } \\
\text { acceptance of their children's homosexuality. }\end{array}$ \\
\hline 7 & $\begin{array}{l}\text { Children's sexual relation- } \\
\text { ships were difficult for } \\
\text { parents to accept }\end{array}$ & $\begin{array}{l}\text { "Initially it was the graphic idea of him having sex with a guy. I } \\
\text { still can't, I try to see the beauty in it, I try and see the love, I try } \\
\text { and get that but then I can't, and it gets too graphic and I just } \\
\text { push it right out. It may be wrong but it is the way I deal with it } \\
\text { and I am great for five years now." In Warren and Wiedenkeller } \\
\text { (1993) and Joubert (1998:20) reference is made of the fact that } \\
\text { parents find it difficult to come to terms with the sexual dimension } \\
\text { of their children's homosexuality. }\end{array}$ \\
\hline 8 & $\begin{array}{l}\text { It is more difficult to accept a } \\
\text { child's homosexuality when } \\
\text { one is older }\end{array}$ & $\begin{array}{l}\text { "..I suppose the older you get the longer it takes to accept } \\
\text { something like that." Savin-Williams (1989:3-4) confirms this } \\
\text { viewpoint and states: "Elderly parents may have more difficulty } \\
\text { accepting their child's homosexuality because of the social and } \\
\text { political climate of their childbearing years when homosexuality } \\
\text { was viewed as an unspeakable, moral sin or a deep psychological } \\
\text { pathology". }\end{array}$ \\
\hline 9 & $\begin{array}{l}\text { Child's problem behaviour } \\
\text { prior to and after the coming- } \\
\text { out }\end{array}$ & $\begin{array}{l}\text { "Before that [referring to the coming-out] I didn't know my child. } \\
\text { He was somebody else ... moody and I couldn't understand what } \\
\text { was wrong with him." } \\
\text { "[Consequent to her son's coming-out...] He sleeps out, he sleeps } \\
\text { outside weekends, he drinks liquor, and he is smoking... } \\
\text { everything like that, making me sad." Saltzburg (2007:59) points } \\
\text { to an array of risk factors surrounding gay/lesbian youths before, } \\
\text { during and subsequent to the coming-out process which, amongst } \\
\text { other things, may include turning to drugs, alcohol, attempted } \\
\text { suicides and sexual encounters to escape their sadness, loneliness } \\
\text { and fears. }\end{array}$ \\
\hline
\end{tabular}




\section{THEME 5: ADVICE OFFERED TO PARENTS REGARDING COPING WITH A CHILD'S COMING OUT}

The participants offered the following advice to other parents in a similar situation:

- Try to understand, love and support them and do not forsake them.

The following quotations are provided in support of this sub-theme:

“All I can say is don't push them away. Don't give them ultimatums like, 'do this, or if you do this, this will happen'. Just try and love them and understand them ... listen to them and sit down and talk to them. Have a conversation with them, not saying, 'this is how I feel and this is what you are supposed to do and this is how it is going to be'. Sit down and talk to them. Listen to them; hear what they have to say..."

"You must love and support your child because they need you more than ever..."

The advice provided above is endorsed by Betty de Generes, mother of the TV-star, Ellen de Generes (in Gideonse, 1997), who says: "Parents, accept the news that [your] child is gay or lesbian and love them and accept them and embrace them just as [you] always did, if not more so, because they need it more ... They need support at home; they get enough negative messages from the world" (Warren \& Wiedenkeller, 1993).

- Educate yourself about homosexuality and about having a gay/lesbian child and how to come to terms with it.

Clarke (1987:53) endorses this sub-theme and states that for a non-gay person (i.e. the parent) to give the true gift of acceptance to a gay/lesbian person is to learn as much as possible about what it means to be gay, and to unlearn the negative stereotypes that are so painful. The comments of the participants relating to this sub-theme were divided into categories and will be presented in the table below and supported by excerpts from the transcriptions to underscore each category; where possible, literature to confirm the research findings will be indicated.

TABLE 5

ADVICE ON HOW TO EDUCATE YOURSELF ABOUT HOMOSEXUALITY AND ABOUT HAVING A GAY/LESBIAN CHILD AND HOW TO COME TO TERMS WITH IT

\begin{tabular}{|c|l|l|}
\hline \multicolumn{2}{|c|}{ Categories } & \multicolumn{1}{c|}{ Excerpts from the interviews } \\
\hline 1 & $\begin{array}{l}\text { Educate yourself by } \\
\text { reading about the topic of } \\
\text { homo-sexuality }\end{array}$ & $\begin{array}{l}\text { ".. read up on the whole subject. Find out as much as you can } \\
\text { and talk to people who understand this thing..." LaSala (2000) } \\
\text { agrees and writes: "In the light of the pervasive influence of } \\
\text { outdated and biased information, parents may need to be re- } \\
\text { educated about gay lifestyles" (Borhek 1988:126; Warren \& } \\
\text { Wiedenkeller, 1993). }\end{array}$ \\
\hline 2 & $\begin{array}{l}\text { Seek professional help, go } \\
\text { for counselling }\end{array}$ & $\begin{array}{l}\text { "I think that soon after finding out [that your child is gay/lesbian] } \\
\text { get some counselling." LaSala (2000) concurs and elaborates: } \\
\text { "Therapy can help a family not only to overcome the coming-out } \\
\text { crisis, (Borhek 1988:127; Warren \& Wiedenkeller, 1993), but } \\
\text { also to improve the relationships and the coping skills." }\end{array}$ \\
\hline 3 & $\begin{array}{l}\text { Get involved in the gay } \\
\text { community }\end{array}$ & $\begin{array}{l}\text { "They are funny, you don't want to mix with them initially, but if } \\
\text { you make friends with them you can share their lives." }\end{array}$ \\
\hline
\end{tabular}




\begin{tabular}{|c|l|l|}
\hline \multicolumn{2}{|c|}{ Categories } & \multicolumn{1}{c|}{ Excerpts from the interviews } \\
\hline 4 & Join a support group & $\begin{array}{l}\text { "Getting a support group for people would be helpful because } \\
\text { when we were in that situation there was no one that you could } \\
\text { really go and talk to ..." } \\
\text { "Yes, yes, suggest a support group where people can talk .. I } \\
\text { feel if other parents can hear some others that they are not the } \\
\text { only ones..." Boxer et al. (in Ben-Ari, 1995a:108) endorse the } \\
\text { idea of a support group and state that support groups provide } \\
\text { parents with information about homo-sexuality, reinforce their } \\
\text { newfound knowledge, and provide them with role models to } \\
\text { support and facilitate their own process of "coming out". }\end{array}$ \\
\hline 5 & $\begin{array}{l}\text { Get support from your own } \\
\text { family }\end{array}$ & $\begin{array}{l}\text { "You need someone to support you in your own family" (Clarke, } \\
1987: 13) .\end{array}$ \\
\hline 6 & Pray about it & $\begin{array}{l}\text { "And another thing that will help is to take it to the Lord because } \\
\text { that is another way that you can find inner peace. Don't try and } \\
\text { carry the burden on your own because you will never make it, } \\
\text { not at all." }\end{array}$ \\
\hline 7 & $\begin{array}{l}\text { "They are not going to change. They are born like that and that } \\
\text { ho not hold onto false } \\
\text { is going to be their lifestyle. The parents in Warren and } \\
\text { Wiedenkeller's (1993) research added the following advice in } \\
\text { this regard: "Don't try and change them or insist that they } \\
\text { change themselves. It won't do any good, and it could be } \\
\text { harmful. Whatever you do, do not reject your child." }\end{array}$ \\
\hline
\end{tabular}

\section{CONCLUSIONS AND RECOMMENDATIONS PERTAINING TO FURTHER AND FUTURE RESEARCH}

The above research findings constitute the experiences of parents regarding the coming-out process of a gay or lesbian child. Based on the research findings and the literature verification, the following conclusions can be drawn:

- Parents experienced a variety of feelings consequent to the coming out of their gay/lesbian child. The feelings experienced included feelings of loss, shock, disappointment, embarrassment, fear, guilt, sadness and hurt, and feelings of relief and happiness.

- The reactions of the participants consequent to the coming out of their gay/lesbian child resembled what is often described in literature as typical "grief reactions" (LaSala, 2000), in that they (amongst other things) grieved about their child's image, which they have nurtured over the years. The participants went through Kübler-Ross's grieving stages, beginning with shock, moving through denial, anger, bargaining, sadness and depression, and eventual acceptance (Ben-Ari, 1995a:93; LaSala, 2000).

- Various factors helped the participants to accept their child's homosexuality. This included relabelling the child's homosexuality as God's plan to support the child, relabelling the child's homosexual identity as something God wanted him/her to have, accepting the child's homosexual identity or face the consequence of losing him/her, realising that it is not a choice to be gay/lesbian, realising that there are many gay people and parents with gay children, reading about homosexuality and how parents with a homosexual child cope, 
realising that the child is happy, accepting the child's homosexual identity, suspecting for some time that their child might be gay/lesbian, and getting support from various sources.

- The following factors complicated the process for the parents in accepting their child's homosexuality: fear of the stigma attached to having a homosexual child, fear of being rejected by friends, fear that the child should show his/her affection to the partner in public, fear of reaction for close family members, the church's stance on homosexuality, parents' own beliefs about homosexuality, finding the sexual aspect of their child's relationship difficult to accept, finding it more difficult to accept a child's homosexuality when one is older, and the child's problems prior to and after coming out.

- The advice given by the participants to other parents in a similar situation included the following: try to understand, love and support them and do not forsake them, and educate yourself about homosexuality and about having a gay or lesbian child and how to come to terms with it.

Based on these conclusions, the following recommendations, specifically to further and future research, are made:

- In view of the fact that this research study was not a reflection of all the population groups comprising the rainbow nation, the researchers want to recommend a follow-up study in this regard, which should comprise a sample specifically including parents from the black, the coloured and the Indian communities.

- It is also recommended that in future a research project (with a qualitative approach) be undertaken on a topic related to this subject, namely the experiences of siblings regarding the coming-out process of a gay brother or lesbian sister.

\section{REFERENCES}

AMNESTY INTERNATIONAL. 1998. Campaigning for lesbian and gay human rights. Gay Times, March, 13-21, 22, 26.

ARMESTO, J.C. 2001. Attributions and emotional reactions to the identity disclosure ("coming out") of a homosexual child, Family Process, 40(2):145. Available: EBSCOhost: Academic Search Premier, Item: AN4766183. [Accessed: 20/11/2002].

BEN-ARI, A. 1995a. The discovery that an offspring is gay: parents', gay men's and lesbians' perspectives. Journal of Homosexuality, 30(1):89-112.

BEN-ARI, A. 1995b. Coming out: a dialectic of intimacy and privacy. Families in Society: The Journal of Contemporary Human Services, 76(5):306-312.

BERZON, B. 2000. Mom, Dad, I'm not going away, Advocate, 29 February: 11. Available: EBSCOhost: Academic Search Premier, Item: AN2828635. [Accessed: 19/08/2001].

BORHEK, M.V. 1988. Helping gay and lesbian adolescents and their families. A mother's perspective. Journal of Adolescent Health Care, 9(2):123-128.

BUTLER, A.H. 2000. A qualitative study on the coming out of gay and lesbian youth. Port Elizabeth: University of Port Elizabeth. (PhD Thesis).

CHAN, C.S. 1989. Issues of identity development among Asian-American lesbians and gay men. Journal of Counselling and Development, 23:45.

CLARKE, D. 1987. Loving someone gay. Millbrae: Celestial Arts. 
CRAMER, D.W. \& \& ROACH, A.J. 1988. Coming out to mom and dad: a study of gay males and their relationships with their parents. Journal of Homosexuality, 15(3/4):79-91.

CRESWELL, J.W. 1994. Research design: qualitative and quantitative approaches. Thousand Oaks: Sage Publications.

CRABTREE, B.F. \& MILLER, W.L. 1999. Doing qualitative research $\left(2^{\text {nd }}\right.$ ed). Thousand Oaks: Sage Publications.

DONALEK, J.G. \& SOLDWISCH, S. 2004. Demystifying nursing research: an introduction to qualitative research methods. Urologic Nursing, 24(4):354-356.

DU PLESSIS, J. 1999. Oor gay wees. Kaapstad: Tafelberg-Uitgewers Beperk.

FALZARANO, A. 1997. New group supports parents. Christianity Today, 41(1):66.

FIELDS, J. 2001. Normal queers: straight parents respond to their children's "coming out", Symbolic Interaction, 24(2):165. Available: EBSCOhost: Academic Search Primer. Item: An4757111. [Accessed: 29/08/2001].

FOSSEY, E., HARVEY, C., McDERMOTT, F. \& DAVIDSON, L. 2002. Understanding and evaluating qualitative research. Australian and New Zealand Journal of Psychiatry, 36:717732.

GABRIEL, R. 2001. Calling all parents, Advocate, 745:32. Available: EBSCOhost: Academic Search Primer, Item: AN971109153. [Accessed: 29/08/2001].

GANONG, L.H. \& COLEMAN, M. 2002. Family resilience in multiple contexts. Journal of Marriage and the Family, 64:346-348.

GIDEONSE, T. 1997. PFLAG'S family crisis, Advocate, 745:32. Available: EBSCOhost: Academic Search Premier, Item: AN9711091531. [Accessed: 29/08/2001].

GOFFMAN, E. 1997. Stigma: notes on the management of spoiled identity. Englewood Cliffs, New Jersey: Prentice Hall.

GREEN, R.-J. 1996. Lesbians, gay men, and their parents: a critique of LaSala and the prevailing clinical 'wisdom', Family Process, 39:257. Available: EBSCOhost: Academic Search Primer, Item: AN3348859. [Accessed: 29/08/2001].

HAMACHEK, D. 1992. Encounters with self ( $4^{\text {th }}$ ed). Michigan State University. New York: Harcourt Brace Javanovich College Publishers.

HAWKINS, R.O. 1996. Counselling lesbian women and gay men: a life issues approach. London: Bell and Howell.

HOLLOWAY, I. \& WHEELER, S. 1996. Qualitative research for nurses. Great Britain: MPG Books Ltd.

JOUBERT, D. 1998. Onlogiese liefde. Op pad met my gay kind. Pretoria: JL van Schaik.

KAY, J. 1997. Mom, dad, I'm gay. You Magazine, January 7:86-87.

KREFTING, L. 1991. Rigor in qualitative research: the assessment of trustworthiness. The American Journal of Occupational Therapy, 45(03):214-222.

KVALE, S. 1996. Interviews: an introduction to qualitative research interviewing. Thousand Oaks: Sage Publications Inc. 
LASALA, M.C. 2000. Lesbian, gay men, and their parents: family therapy for the coming-out crisis, Family Process, 39(1):67. Available: EBSCOhost: Academic Search Premier, Item: AN3024409. [Accessed: 29/08/2001].

MORRIS, C.G. 1996. Psychology: an introduction $\left(9^{\text {th }}\right.$ ed). New York: Prentice Hall Press.

MOSES, A.E. 1986. Counselling lesbian women and gay men. London: Merrill Publishing Company.

NEUMAN, W.L. 1997. Social research methods: qualitative and quantitative approaches. London: Allyn \& Bacon.

REPSOLD, R. 1997. A mother's story. In: GERMOND, P. \& DE GRUNCHY, S. (eds) Aliens in the household of God. Homosexuality and faith in South Africa. Cape Town: David Phillips.

SALTZBURG, S. 2007. Narrative therapy pathways for re-authoring with parents of adolescents coming-out as lesbian, gay and bisexual. Contemporary Family Therapy, 29:5769.

SAVIN-WILLIAMS, R.C. 1989. Coming out to parents and self-esteem among gay and lesbian youth. Journal of Homosexuality, 18(1/2):1-35.

THOMAS, M.B. 1992. An introduction to marital and family therapy. Counselling toward healthier family systems across the lifespan. New York: Maxwell Macmillan International.

WARREN, A. \& WIEDENKELLER, J. 1993. When sons and daughters are gay or lesbian. Mothering, 69:54. Available: EBSCOhost: MasterFILE Premier, Item: AN9402235148. [Accessed: 29/08/2001].

WOOG, D. 1997. Our parents, Advocate, 745:24. Available: EBSCOhost: Academic Search Premier, Item: AN9711091529. [Accessed: 18/11/2002].

Dr Assim Alpaslan, Senior Lecturer, Department of Social Work, University of South Africa, Pretoria, South Africa.

Ms Theresa Johnston, Social Worker, Child Protection Unit, Port Elizabeth, South Africa.

Ms Veonna Goliath, Lecturer, Department of Social Development Professions, Nelson Mandela Metropolitan University, Port Elizabeth, South Africa. 